\title{
New Disease Reports \\ First report of bacterial spot caused by Xanthomonas cucurbitae on pumpkin in Italy
}

\author{
I. Altin ${ }^{1}$, L. Casoli ${ }^{2}$ and E. Stefani ${ }^{1 *}$ \\ ${ }^{1}$ Department of Life Sciences, University of Modena and Reggio Emilia, via Amendola 2, 42122 Reggio Emilia, Italy ; ${ }^{2}$ \\ Consorzio Fitosanitario Provinciale, via Gualerzi 32, 42124 Reggio Emilia, Italy
}

*E-mail: emilio.stefani@unimore.it

Received: 23 Jan 2020. Published: 16 Apr 2020. Keywords: bacterial disease, cucurbits, watermelon, Xanthomonadaceae

In 2018, a disease outbreak was observed on pumpkin (Cucurbita moschata cv. Violina) in the municipality of Reggio Emilia (Northern Italy). Symptoms were observed on leaves and fruits. On leaves, chlorotic spots appeared in July, after a period of rainstorms, later turning necrotic and coalescing (Fig. 1). On fruits, small, brown spots developed (Fig. 2); some necrotic spots became infected by saprophytes and developed rots (Fig. 3). In the affected field, around $90 \%$ of fruits were diseased, leading to a total loss of production. In summer 2019, the disease was again observed in the same and neighbouring municipalities affecting two pumpkin varieties $(C$. moschata cv. Violina and C. maxima cv. Mantovana), displaying the same symptoms as in the previous year (Fig. 4). Symptoms were also observed on watermelon; small necrotic spots developed on leaves, only rarely confluent in large necrotic areas (Fig. 5) whereas, on fruits, no symptom was noted.

Isolation from symptomatic tissue was attempted on glucose yeast chalk agar medium. Bright yellow and mucoid colonies, with entire margins, developed after $48-60$ hours at $28^{\circ} \mathrm{C}$. Individual colonies were further purified for identification. Pathogenicity of isolates was confirmed on young pumpkin plants (C. moschata and C. maxima, 4 to 6 true leaves) by spraying a bacterial suspension $\left(10^{7} \mathrm{cfu} / \mathrm{ml}\right)$ on the canopy; inoculated plants were then kept in a glasshouse and observed for symptom development for up to three weeks. Re-isolated bacteria were identical to the original strains as determined by rep-PCR, thereby fulfilling Koch's postulates. Simplex-PCR with Xanthomonas cucurbitae genus-specific primers (RST2/RST3) produced a $1.4 \mathrm{~kb}$ amplicon, similar to $X$. cucurbitae, type strain CFBP 2542. Isolate identity was confirmed by sequencing of the $g y r \mathrm{~B}, r p o \mathrm{D}, f y u \mathrm{~A}$ and $d n a \mathrm{~K}$ housekeeping genes (GenBank Accession Nos.: gyrB: MT110622, rpoD: MT215599, fyuA: MT110623 dnaK, MT227561). BLAST comparison of representative isolates in GenBank showed 99.76-100\% identity with X. cucurbitae strains (ICMP 2299, ICMP 2179, ICMP 4767). Therefore, the pathogenic xanthomonads isolated in the province of Reggio Emilia were identified as Xanthomonas cucurbitae.

Prior to 1980, a few unconfirmed records of the pathogen were reported in the former Soviet Union (Kiryukhina, 1980). More recently, bacterial spot of pumpkins was reported in India, China and Nepal (Lamichhane et al., 2010). Bacterial spot of pumpkin is also present in other countries, such as the USA, where it may cause up to $90 \%$ crop loss in infected fields (Babadoost \& Ravanlou, 2012) and in Canada (Trueman et al., 2014) Recently, the cause of leaf spot of pumpkin affecting fields in Styria

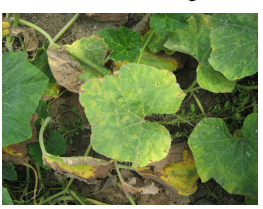

Figure 1

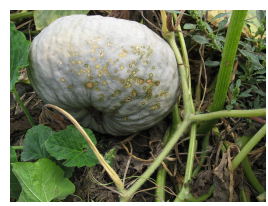

Figure 4

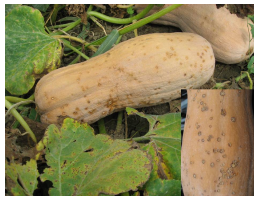

Figure 2

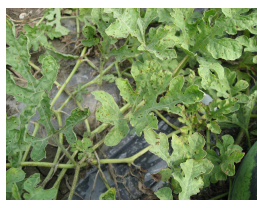

(Austria) was attributed to a set of phytopathogenic bacteria, including $X$. cucurbitae (Huss, 2011), although no official identification was completed. This is the first confirmed report of bacterial spot of pumpkin, followed by isolation, identification and characterisation of its causal agent, Xanthomonas cucurbitae, in Italy and Europe. The geographical origin of the pathogen is unknown, but its introduction might be connected with the international trade of pumpkin seed. Our observation of $X$. cucurbitae leaf spot on watermelon supports the report of Dutta et al. (2013). Further research is needed to assess the host range of the Italian isolates of $X$. cucurbitae amongst cucurbits.

\section{Acknowledgements}

Research conducted in the framework of the EU-COST Action CA16107 "EuroXanth: Integrating Science on Xanthomonadaceae".

\section{References}

1. Babadoost M, Ravanlou A, 2012. Outbreak of bacterial spot (Xanthomonas cucurbitae) in pumpkin fields in Illinois. Plant Disease 96, 1222. http://dx.doi.org/10.1094/PDIS-03-12-0241-PDN

2. Dutta B, Gitaitis RD, Lewis KJ, Langston DB, 2013. A new report of Xanthomonas cucurbitae causing bacterial leaf spot of watermelon in Georgia, USA. Plant Disease 94, 556 http://dx.doi.org/10.1094/PDIS-10-12-0908-PDN

3. Huss H, 2011. Krankheiten und Schädlinge im Ölkürbisbau. Der fortschrittliche Landwirt, 3, 30-33.

4. Kiryukhina RI, 1980 Diagnostics of Bacterial Diseases of Vegetable Cultures and Measures of Their Control. Moscow, Russia: Russian Academy of Agricultural Sciences (in Russian).

5. Lamichhane JR, Varvaro L, Balestra GM, 2010. Bacterial leaf spot caused by Xanthomonas cucurbitae reported on pumpkin in Nepal. New Disease Reports 22, 20. http://dx.doi.org/10.5197/j.2044-0588.2010.022.020

6. Trueman CL, Roddy E, Goodwin PH, 2014. First report of bacterial spot (Xanthomonas cucurbitae) of pumpkin in Ontario, Canada. New Disease Reports 30, 8.

http://dx.doi.org/10.5197/j.2044-0588.2014.030.008

To cite this report: Altin I, Casoli L, Stefani E, 2020. First report of bacterial spot caused by Xanthomonas cucurbitae on pumpkin in Italy. New Disease Reports 41, 21. http://dx.doi.org/10.5197/j.2044-0588.2020.041.021 